\title{
Freshwater flux to Sermilik Fjord, SE Greenland
}

\author{
S. H. Mernild ${ }^{1}$, I. M. Howat ${ }^{2}$, Y. Ahn ${ }^{2}$, G. E. Liston ${ }^{3}$, K. Steffen ${ }^{4}$, B. H. Jakobsen ${ }^{5}$, B. Hasholt ${ }^{5}$, B. Fog , and D. van $^{5}$ \\ As $^{6}$ \\ ${ }^{1}$ Climate, Ocean, and Sea Ice Modeling Group, Computational Physics and Methods (CCS-2), Los Alamos National \\ Laboratory, New Mexico, USA \\ ${ }^{2}$ Byrd Polar Research Center and School of Earth Sciences, Ohio State University, Ohio, USA \\ ${ }^{3}$ Cooperative Institute for Research in the Atmosphere, Colorado State University, Colorado, USA \\ ${ }^{4}$ Cooperative Institute for Research in Environmental Sciences, University of Colorado, Colorado, USA \\ ${ }^{5}$ Department of Geography and Geology, University of Copenhagen, Denmark \\ ${ }^{6}$ Geological Survey of Denmark and Greenland, Denmark
}

Received: 29 June 2010 - Published in The Cryosphere Discuss.: 30 July 2010

Revised: 13 October 2010 - Accepted: 16 October 2010 - Published: 26 October 2010

\begin{abstract}
Terrestrial inputs of freshwater flux to Sermilik Fjord, SE Greenland, were estimated, indicating ice discharge to be the dominant source of freshwater. A freshwater flux of $40.4 \pm 4.9 \times 10^{9} \mathrm{~m}^{3} \mathrm{y}^{-1}$ was found (1999-2008), with an $85 \%$ contribution originated from ice discharge $(65 \%$ alone from Helheim Glacier), $11 \%$ from terrestrial surface runoff (from melt water and rain), 3\% from precipitation at the fjord surface area, and $1 \%$ from subglacial geothermal and frictional melting due to basal ice motion. The results demonstrate the dominance of ice discharge as a primary mechanism for delivering freshwater to Sermilik Fjord. Time series of ice discharge for Helheim Glacier, Midgård Glacier, and Fenris Glacier were calculated from satellitederived average surface velocity, glacier width, and estimated ice thickness, and fluctuations in terrestrial surface freshwater runoff were simulated based on observed meteorological data. These simulations were compared and bias corrected against independent glacier catchment runoff observations. Modeled runoff to Sermilik Fjord was variable, ranging from $2.9 \pm 0.4 \times 10^{9} \mathrm{~m}^{3} \mathrm{y}^{-1}$ in 1999 to $5.9 \pm 0.9 \times 10^{9} \mathrm{~m}^{3} \mathrm{y}^{-1}$ in 2005. The sub-catchment runoff of the Helheim Glacier region accounted for $25 \%$ of the total runoff to Sermilik Fjord. The runoff distribution from the different sub-catchments suggested a strong influence from the spatial variation in glacier coverage, indicating high runoff volumes, where glacier cover was present at low elevations.
\end{abstract}

\section{Correspondence to: S. H. Mernild} (mernild@lanl.gov)

\section{Introduction}

Global atmospheric temperatures showed a warming trend since the 1970s, and all years during the present century (2001-2008) have been among the warmest since the beginning of instrumental records (Allison et al., 2009). Surface air temperature observations reveal the strongest increase occurring over Northern Hemisphere land areas $\left(40-70^{\circ} \mathrm{N}\right)$ since the 1970s; an increase almost twice the global average rate (IPCC, 2007), accompanied by a $\sim 1 \%$ decade $^{-1}$ increase in precipitation (ACIA, 2005). However, for the past decades the strongest increases in temperature have been over the Arctic Ocean in autumn and winter, in response to loss of the insulating Arctic sea ice cover (Screen and Simmonds, 2010).

There is clear evidence of increased melting of the Greenland Ice Sheet (GrIS) and marginal glaciers in Greenland since the mid-1990s (e.g., Mote, 2007; Tedesco, 2007; Knudsen and Hasholt, 2008; Steffen et al., 2008), and rapid mass loss has been observed and simulated (e.g., Hanna et al., 2008; Allison et al., 2009; Khan et al., 2010). In a warming climate, we would expect an accelerating freshwater flux: ice discharge (calving) and runoff to the ocean, manifested by, e.g., decreasing ocean salinity, and increasing global eustatic sea level rise (e.g., ACIA, 2005; Box et al., 2006; IPCC, 2007; Mernild et al. 2011). A few freshwater runoff measurements are available for Greenland from the 1990s at the Sermilik Research Station, Sermilik Fjord $\left(65^{\circ} \mathrm{N}\right)$, SE Greenland (Fig. 1), and at the Zackenberg Research Station, Young Sund/Tyroler Fjord $\left(74^{\circ} \mathrm{N}\right)$, NE Greenland, and shorter term measurements are available

Published by Copernicus Publications on behalf of the European Geosciences Union. 

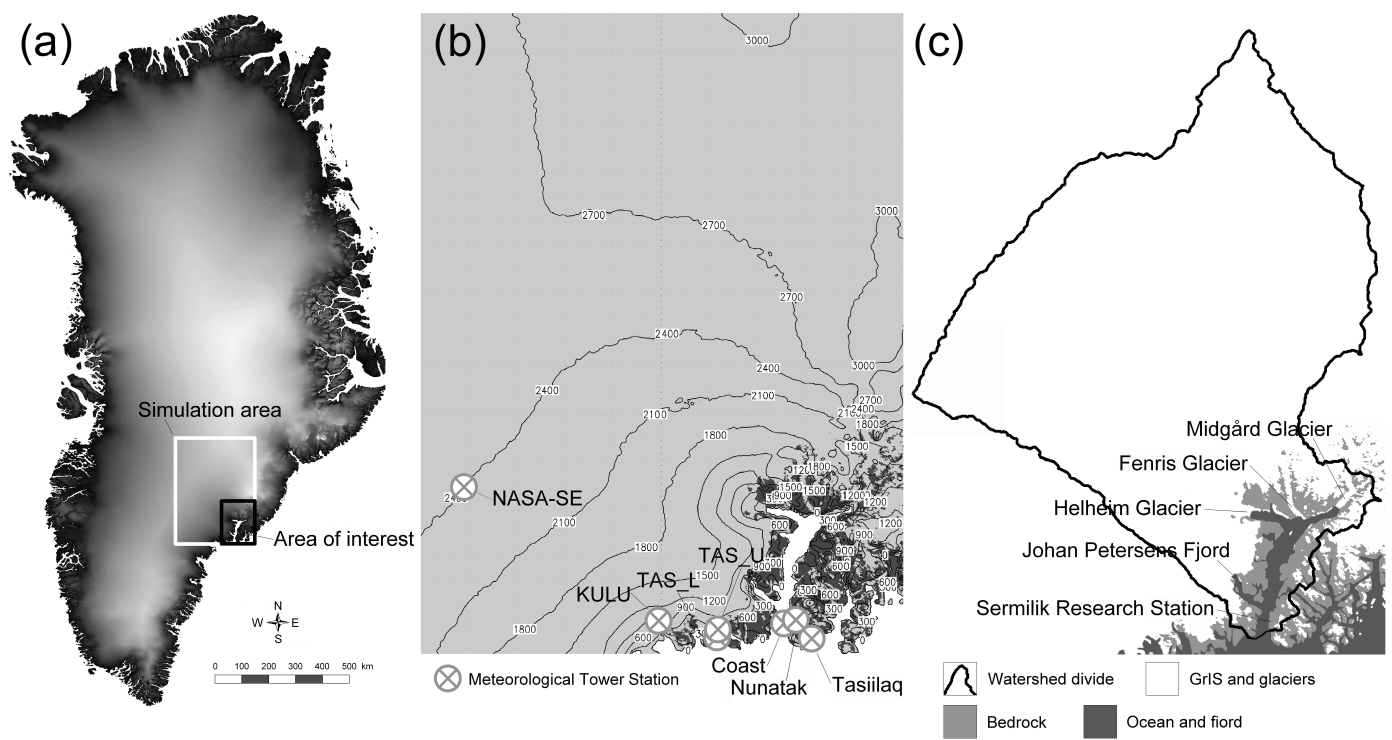

Fig. 1. (a) Greenland, including the Sermilik Fjord simulation domain $\left(120350 \mathrm{~km}^{2}\right)$ and area of interest $\left(18750 \mathrm{~km}{ }^{2}\right)$ in South East Greenland; (b) Sermilik Fjord with topography (300-m contour interval) and meteorological stations (see Table 1 for station information); and (c) MODIS satellite-derived surface characteristics (30 August 2009), including catchment (58 $045 \mathrm{~km}^{2}$ ), watershed divide, and locations of GrIS outlet glaciers. The surface watershed divide is estimated based on the program RiverTools (http://www.rivertools.com/): a GIS application for analysis and visualization of digital terrain, watersheds, and river network.

from Kangerlussuaq (Søndre Strømfjord), Kangerlussuaq Fjord $\left(67^{\circ} \mathrm{N}\right)$, W Greenland, since 2007, and from Kobberfjord $\left(64^{\circ} \mathrm{N}\right), \mathrm{W}$ Greenland, since 2008 (e.g., Mernild and Hasholt, 2006, 2009; Jensen and Rasch, 2009). These data series are important tools for assessing and quantifying the impact of climate change and variability on freshwater runoff from glaciated landscapes such as Greenland.

The first documentation of glaciers in the Sermilik Fjord catchment basin was carried out in 1933, and in 1970 the Sermilik Research Station was established close to the Mittivakkat Glacier to study the control of climate on a low-arctic (Born and Böcher, 2001), partly glaciated landscape. An automated terrestrial monitoring program was initiated for the Mittivakkat Glacier catchment in 1993, which presents today the longest continuous monitoring program in E Greenland. Data on observed climate conditions have been presented by Mernild et al. (2008a) and Jakobsen et al. (2008). Seasonal and annual observations on the Mittivakkat Glacier include: winter, summer, and net mass-balance (Knudsen and Hasholt, 2004, 2008), freshwater runoff (e.g., Hasholt, 1980; Hasholt and Mernild, 2004, 2008), and sediment transport (Hasholt and Walling, 1992; Busskamp and Hasholt, 1996; Hasholt and Mernild, 2008). Modeling studies for this region include seasonal and annual climate processes (Mernild and Liston, 2010), snow cover distribution (Hasholt et al., 2003; Mernild et al., 2006a), glacier surface mass-balance (Mernild et al., 2006a, 2008b), and runoff (Mernild and Hasholt, 2006; Mernild et al., 2008b).
This collection of extensive observations and model results from the Mittivakkat Glacier catchment was used to simulate the terrestrial surface runoff for the Sermilik Fjord (the study does not include ocean fluxes). Not only runoff but also ice discharge from e.g., the Helheim Glacier (one of the most conspicuous calving outlet glaciers from the GrIS) at the innermost part of the fjord, seems to be an important source of freshwater for both, the Sermilik Fjord and the Irminger Sea. We present a 10-year time series (19992008) of freshwater flux to the Sermilik Fjord in order to assess variability and trend thereof due to changes in air temperature, net precipitation (hereafter referred to as precipitation), and ice dynamics. In particular, we address the simulated temporal and spatial distribution of terrestrial surface freshwater runoff to the fjord and also on a sub-catchment scale. The runoff was simulated in SnowModel (Liston and Elder, 2006a; Mernild et al., 2006a) - a state-of-the-art modeling system, based on in situ meteorological data within the Sermilik Fjord area. Runoff was initially simulated for the Mittivakkat Glacier catchment area of $\sim 18 \mathrm{~km}^{2}$ and tested against observed runoff data from the Mittivakkat Glacier catchment outlet which is the only place in the Sermilik Fjord where runoff is observed. The simulated runoff was bias corrected against runoff observations, before runoff simulations were scaled up to the entire Sermilik Fjord catchment area. The following objectives are addressed: (1) assess the performance of SnowModel by comparing simulated runoff against observed runoff for the Mittivakkat Glacier catchment; (2) simulate the spatial runoff variability and 
quantify whether the annual freshwater runoff to the Sermilik Fjord has been increasing throughout the simulation period; (3) compare simulated runoff with observed Helheim ice discharge to illustrate the respective distribution from each freshwater source; and (4) merge different sources of freshwater input, e.g., simulated runoff, simulated precipitation over the fjord with satellite-derived ice discharge and geothermal and frictional melting due to basal ice motion to quantify the freshwater flux to the Sermilik Fjord.

\section{Study area}

\subsection{Physical settings and climate}

The Sermilik Fjord catchment $\left(58045 \mathrm{~km}^{2}\right)$ is located on the east coast of Greenland $\left(65^{\circ} \mathrm{N}, 37^{\circ} \mathrm{W}\right)$, connected to the Irminger Sea (Fig. 1a). The fjord is $1103 \mathrm{~km}^{2}$ in area, $85 \mathrm{~km}$ in length, and the largest fjord system in SE Greenland. The catchment drains a part of the GrIS, including the Helheim, Fenris, and Midgård Glaciers (the three major outlet glaciers in Sermilik Fjord catchment), and marginal glaciers, among these the Mittivakkat Glacier on Ammassalik Island (see Figs. 1c and 3a for location), where longterm monitoring of climate, mass-balance, and runoff was observed (Mernild and Hasholt, 2006; Knudsen and Hasholt, 2008). The Sermilik Fjord catchment ranges in elevation from sea level to $\sim 2900 \mathrm{~m}$ a.s.l. The lower parts of the terrain (elevation below 700-1000 ma.s.1.) are dominated by exposed bedrock, sporadic thin soil layers, and sparse vegetation. Landscapes above 700-1000 m a.s.l. are mostly covered by glaciers and the GrIS (Fig. 1c). For the purposes of this study, the Sermilik Fjord catchment has been divided into seven sub-catchments, each draining into specific parts of the fjord. These areas also represent characteristic variations in glacier ice coverage from approximately 10\% (area 2) to $87 \%$ (area 4) (Figs. 1c and 4f).

The Sermilik Fjord region represents one of the most humid parts of Greenland (the zone of largest annual precipitation is located $\sim 200 \mathrm{~km}$ further south). The simulated mean annual air temperature (MAAT, 2-m above the surface) for the full catchment including the GrIS was $-4.8^{\circ} \mathrm{C}$ (1999-2008), varying from around the freezing point at the near coastal stations (Tasiilaq and Coast Stations) to around $-19^{\circ} \mathrm{C}$ on the GrIS (Station NASA-SE) (Fig. 2a). The total annual simulated precipitation (corrected after Allerup et al., 1998, 2000; for further information about the detailed precipitation correction procedures, see Mernild et al., 2009, 2010 a) varied from $\sim 1200$ to $\sim 1800 \mathrm{~mm}$ w.eq. $\mathrm{y}^{-1}$ within the catchment. Our simulated precipitation values were almost in the same order of magnitude compared to spatial values (1958-2007 average) from Ettema et al. (2009) of 1000 up to $3000 \mathrm{~mm}$ w.eq. $\mathrm{y}^{-1}$. Mean annual catchment relative humidity and wind speed were $83 \%$ and $4.1 \mathrm{~m} \mathrm{~s}^{-1}$, respectively.
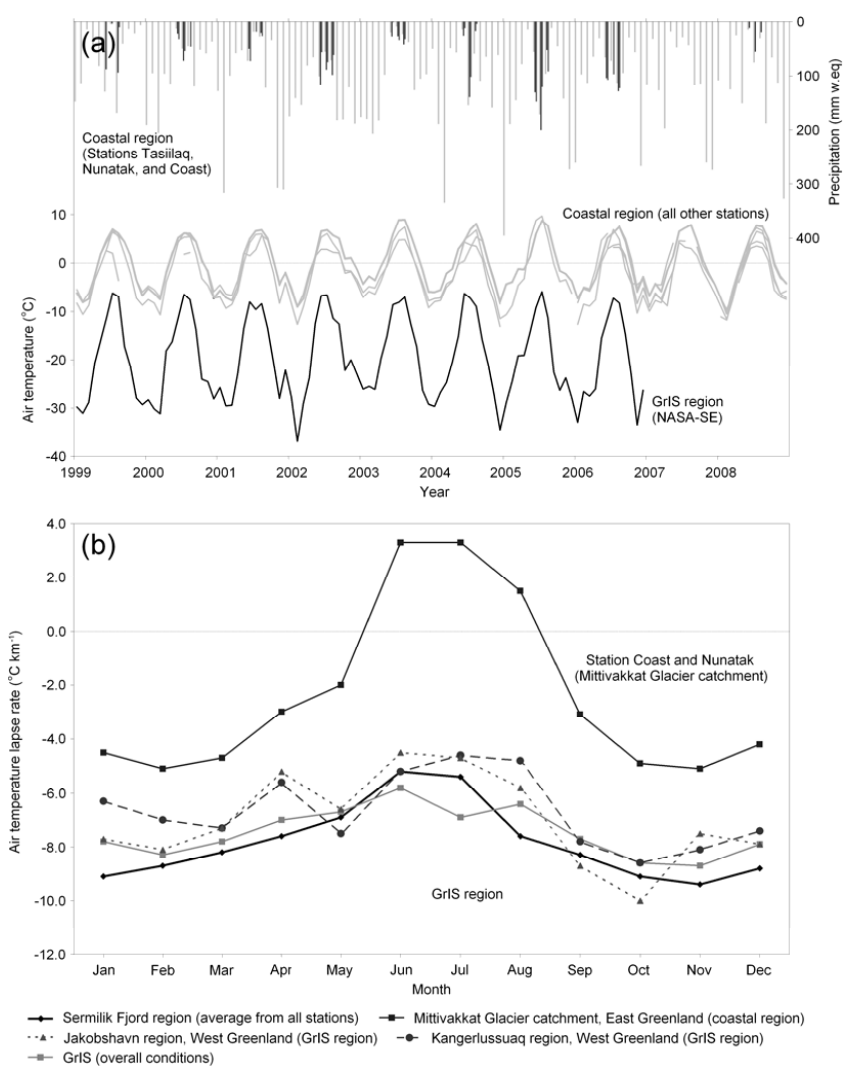

Fig. 2. (a) Time series of observed mean monthly air temperature from coastal (Station Tasiilaq, Coast, Nunatak, TAS_U, TAS_L, and KULU) and GrIS stations (NASA-SE). Observed cumulative monthly precipitation from coastal stations (Tasiilaq; light color, and Coast and Nunatak (June, July, and August); dark colors) are illustrated; and (b) mean monthly air temperature lapse rates for all the meteorological stations in the simulation domain, for Station Coast and Nunatak (Mernild et al., 2006), and for different areas around the GrIS are illustrated (Mernild et al., 2009).

During summer, the low lying coastal areas, on, e.g., Ammassalik Island (approximately below $300 \mathrm{~m}$ a.s.l.), are influenced by air temperature inversions which are common in Arctic coastal landscapes, due to the effect of sea breezes associated with thermal differences between land and the frequently ice-choked fjord and ocean (e.g., Kozo, 1982; Weick and Rouse, 1991; Mernild and Liston, 2010). The climate and its seasonal variability are illustrated in Fig. $2 \mathrm{~b}$ using positive summer air temperature lapse rates in the near coastal areas. Apart from this temperature inversion in the lower lying near coastal areas during summer, observed air temperature data from all seven stations in the Sermilik Fjord catchment (Fig. 1) showed constantly negative mean monthly temperature lapse rates, very similar to the high-elevation GrIS temperature lapse rates (Fig. 2a) (e.g., Steffen and Box, 2001; Mernild et al., 2009). 
Table 1. Meteorological input data for the Sermilik Fjord simulation based on meteorological station data on the GrIS: KULU and NASA-SE (provided by University of Colorado at Boulder) and TAS_L and TAS_U (by Geological Survey of Denmark and Greenland (GEUS)), and from the outside the GrIS: Station Tasiilaq (by Danish Meteorological Institute (DMI)) and Station Coast and Station Nunatak (by University of Copenhagen, Department of Geography and Geology). The abbreviations indicate: (Ta) air temperature, (RH) relative humidity, (Ws) wind speed, $(\mathrm{Wd})$ wind direction, and $(P)$ precipitation. For station locations see Fig. $1 \mathrm{~b}$.

\begin{tabular}{|c|c|c|c|c|c|c|}
\hline $\begin{array}{l}\text { Meteorological } \\
\text { station }\end{array}$ & Location & Grid & $\begin{array}{l}\text { Elevation } \\
\text { (ma.s.l.) }\end{array}$ & Data period & Parameters & Operated by \\
\hline KULU & GrIS & $65^{\circ} 45^{\prime} \mathrm{N} ; 39^{\circ} 36^{\prime} \mathrm{W}$ & 880 & 20 Jun 1999 - 13 Sep 2000 & $T \mathrm{a}, \mathrm{RH}, \mathrm{Ws}$, and $\mathrm{Wd}$ & University of Colorado at Boulder \\
\hline NASA-SE & GrIS & $66^{\circ} 28^{\prime} \mathrm{N} ; 42^{\circ} 30^{\prime} \mathrm{W}$ & 2390 & 1 Jan 1999 - 25 May 2005 & $T \mathrm{a}, \mathrm{RH}, \mathrm{Ws}$, and Wd & University of Colorado at Boulder \\
\hline TAS $\_$ & GrIS & $65^{\circ} 38^{\prime} \mathrm{N} ; 38^{\circ} 54^{\prime} \mathrm{W}$ & 270 & 26 Jun $2006-31$ Dec 2008 & $T \mathrm{a}, \mathrm{RH}, \mathrm{Ws}$, and Wd & GEUS \\
\hline TAS_U & GrIS & $65^{\circ} 42^{\prime} \mathrm{N} ; 38^{\circ} 52^{\prime} \mathrm{W}$ & 580 & 16 Apr $2004-31$ Dec 2008 & $T \mathrm{a}, \mathrm{RH}, \mathrm{Ws}$, and $\mathrm{Wd}$ & GEUS \\
\hline Tasiilaq & Outside GrIS & $65^{\circ} 36^{\prime} \mathrm{N} ; 37^{\circ} 38^{\prime} \mathrm{W}$ & 44 & 1 Sep 1998 - 31 Aug 2009 & $T \mathrm{a}, \mathrm{RH}, \mathrm{Ws}, \mathrm{Wd}$, and $P$ & DMI \\
\hline Coast & Outside GrIS & $65^{\circ} 41^{\prime} \mathrm{N} ; 37^{\circ} 55^{\prime} \mathrm{W}$ & 25 & 1 Jan $1999-31$ Dec 2008 & $T \mathrm{a}, \mathrm{RH}, \mathrm{Ws}, \mathrm{Wd}$, and $P$ & University of Copenhagen \\
\hline Nunatak & Outside GrIS & $65^{\circ} 42^{\prime} \mathrm{N} ; 37^{\circ} 49^{\prime} \mathrm{W}$ & 515 & 1 Jan $1999-31$ Dec 2008 & $T \mathrm{a}, \mathrm{RH}, \mathrm{Ws}, \mathrm{Wd}$, and $P$ & University of Copenhagen \\
\hline
\end{tabular}

\section{Model description and satellite data}

\subsection{SnowModel and model simulations}

SnowModel (Liston and Elder, 2006a), is a spatiallydistributed snow-evolution, ice melt, and runoff modeling system designed to be applicable over a wide range of snow and glacier landscapes, and climates found around the world, where snow and ice variations play an important role in hydrological cycling (Mernild et al., 2006a; Mernild and Liston, 2010). For a detailed description of SnowModel, including its subprograms and tests see Liston and Elder (2006a, b), Liston et al. (2008), Liston and Hiemstra (2008), and Mernild and Liston (2010): MicroMet is a quasi-physically based meteorological distribution model, which defines the meteorological forcing conditions, EnBal calculates the surface energy exchanges, including melt, SnowPack simulates heat- and mass-transfer processes and snow-depth and water equivalent evolution, and SnowTran-3D is a blowing-snow model that accounts for snow redistribution by wind. SnowModel is a surface model simulating first-order effects of atmospheric forcing on snow, glacier ice, and runoff, but processes related to glacier dynamics are not included.

\subsection{Input data, model bias correction, and uncertainties}

Meteorological data of air temperature, relative humidity, wind speed, wind direction, and precipitation were obtained from seven meteorological stations at different elevations within the simulation domain (Fig. 1b). Four stations were located on the GrIS, and three outside the GrIS in the coastal region (Table 1). Simulations were preformed on a oneday time step, based on lapse rates, generated using observed data from all seven stations (Fig. 2b). The simulation period spans from 1 September 1998 through $31 \mathrm{Au}-$ gust 2009, whereas output values were simulated for calendar years (1999-2008). Air temperature and precipitation data are summarized in Fig. 2a.
The Greenland topographic data at 625-m resolution from Bamber et al. (2001) was used with the image-derived correction published by Scambos and Haran (2002), and interpolated to a $500-\mathrm{m}$ grid increment covering a 400.5 by $300.5 \mathrm{~km}$ simulation domain for the Sermilik Fjord catchment (Fig. 1a). The location of the Sermilik Fjord coast line, GrIS terminus, and marginal glaciers were estimated by using Moderate Resolution Imaging Spectroradiometer (MODIS) satellite images (observed on 30 August 2009). User-defined constants for SnowModel are shown in Mernild et al. (2009), and parameter definitions are given in Liston and Sturm (1998).

SnowModel simulated runoff was tested and bias corrected against observed runoff from the outlet of the Mittivakkat Glacier catchment for the period 1999-2005 (different observed runoff periods were used, due to variations in field campaign from year to year; Fig. 3a). The cumulative simulated runoff was initially underestimated by $34-43 \%$, averaging 38\% according to runoff observations (Fig. 2). Therefore, a linear regression $\left(r^{2}=0.95\right.$; where $r^{2}$ is the explained variance) was used for runoff correction as shown in Fig. 3a. The corrected cumulative annual Mittivakkat Glacier runoff is illustrated in Fig. 3b. This underestimation of runoff is expected to be a mixture of various causes, where the first three are expected to be the main reasons: (1) uncertainties associated with model inputs (e.g., Mernild and Liston 2010); (2) unrepresented or poorly-represented processes in SnowModel (Liston and Elder 2006a, b); (3) uncertainties related to runoff observations (Hasholt et al., 2006; Mernild and Hasholt, 2009); and (4) englacial and subglacial water flow to/from neighboring glacier sub-catchments (see Mernild 2006, Mernild et al., 2006b; a description of the Mittivakkat Glacier watershed divides can be seen in Mernild and Hasholt (2006). 
The assumed accuracy of single outlet discharge measurements is within $5-10 \%$, whereas calculated stage-discharge values might deviate up to $25 \%$ from simultaneous manual measurements. However, long-term discharges (monthly and annual) are typically accurate within approximately 5-15\% (Hasholt et al., 2006; Mernild and Hasholt, 2009). Statistical analysis from previous SnowModel studies on snow distributions, snow and glacier melt, and runoff from marginal glaciers in Greenland and the GrIS (e.g., Mernild et al., 2006a, 2009), along with uncertainties in observed discharge used for calibration, indicates that simulated influx of runoff to the Sermilik Fjord might be influenced by the same order of uncertainties: We assume an error of $10-25 \%$. This includes uncertainties related to not using routines for air temperature inversion in low lying near coastal areas (Mernild and Liston, 2010) and the associated influence on snow and glacier ice melt and glacier mass-balance simulations; unfortunately no radiosonde data exist for the inner part of the Sermilik Fjord.

Even though SnowModel underestimated runoff by $38 \%$ on average before bias-correction, it is currently probably the most physically realistic model for simulating snow and ice melt, and water balance components, including freshwater runoff from snow- and ice-covered regions. The model demands limited input data, an important consideration in the Sermilik Fjord and other Arctic areas, for which data are sparse due to rough terrain, harsh climatic conditions, and remote location.

\subsection{Satellite-derived ice discharge}

Time series of ice flux to the calving front, which will equal the sum of ice lost to calving and melt at the calving face, and which we term discharge, for Helheim Glacier, Midgård Glacier, and Fenris Glacier were calculated from observed average surface velocity, glacier width and estimated ice thickness. Speeds were measured from automated RepeatImage Feature Tracking (RIFT) using pairs of orthorectified images from: (1) Landsat 7 Enhanced Thematic Mapper Plus (panchromatic band) distributed by the United States Geological Survey; (2) visible to near-infrared bands of the Advanced Spaceborne Thermal Emissivity and reflection Radiometer (ASTER) distributed by the NASA Land Processes Distributed Active Archive (LP DAAC); and (3) SPOT-5 panchromatic images distributed through the SPIRIT program. Landsat and ASTER images have a pixel resolution of $15 \mathrm{~m}$ and the $5 \mathrm{~m}$ SPOT-5 images were down-sampled to $15 \mathrm{~m}$ for RIFT processing. The Multi-Image/Multi-Chip (MIMC) RIFT algorithm (Ahn and Howat, 2010) was used to measure surface displacements every $100 \mathrm{~m}$. Individual displacement vectors were then averaged over a $1-\mathrm{km}$ wide band near the front of the glacier to provide a time series of average velocity at the ice front. Errors in this velocity estimate are the sum of the ambiguity cross-correlation peak (typically $5 \mathrm{~m}$ ) and errors in image co-registration, which can
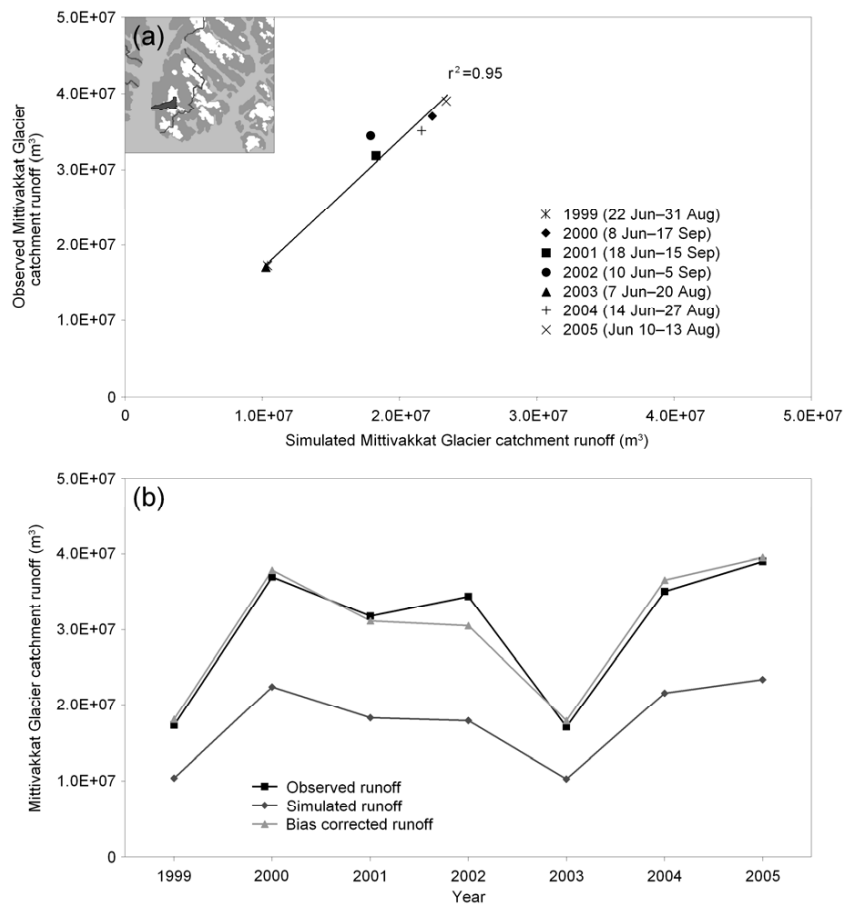

Fig. 3. (a) Observed and simulated Mittivakkat Glacier catchment runoff from 1999-2005. The linear regression (forced through zero) was used for bias correction of the Sermilik Fjord simulated runoff. Be aware that the annual observed runoff periods are different. The inset figure indicates the general location of the Mittivakkat Glacier catchment (black polygon) within sub-catchment area 1 (for a general location of the sub-catchments see Fig. 4a) inside the Sermilik Fjord catchment; and (b) observed, simulated, and bias corrected runoff from the Mittivakkat Glacier catchment from 1999-2005.

vary from several meters to several 10's of meters, following manual registration correction procedures, depending on the image pair. Due to the high speeds observed, we assumed that speed was constant with ice depth. Averaged glacier width over the region of velocity sampling was obtained from 15-m Landsat imagery.

Ice thickness for Helheim Glacier was obtained in 2001 and 2008 by the University of Kansas Coherent Radar Depth Sounder (CoRDS) (Gogineni et al., 2001; Howat et al., 2005). For Fenris and Midgård glaciers, for which no thickness data are available, ice thickness at the start of the time series was estimated from the height of the calving front assuming a grounded ice front at hydrostatic equilibrium and densities of ice and sea water of 910 and $1027 \mathrm{~kg} \mathrm{~m}^{3}$, respectively. We assume an error of $\pm 50 \mathrm{~m}$ in this thickness estimate. Changes in ice thickness through time were then measured from repeat ASTER digital elevation models produced by the LP DAAC and vertically co-registered using tie points over ice-free terrain. These data have a relative error of $\pm 10 \mathrm{~m}$ in the vertical (Fujisada et al., 2005). Overall, we assume an ice discharge error of $15-25 \%$. 


\subsection{Geothermal and frictional melting due to basal ice motion}

The upper-bounds for the melt water generated through melting at the ice bed due to: (a) geothermal heating; and (b) frictional heating due to basal ice motion were estimated. For (a), it was liberally assumed that the bed was at the melting temperature over all regions with surface elevations below $1200 \mathrm{~m}$ a.s.l., and area of $2300 \mathrm{~km}^{2}$. A typical geothermal heat flux of $0.05 \mathrm{~W} \mathrm{~m}^{-2}$ gives a basal melt rate of $5 \mathrm{~mm}$ w.eq. $\mathrm{y}^{-1}$ (Cuffey and Paterson, 2010, p. 118) for ice at the melting temperature, totaling approximately $0.01 \times 10^{9} \mathrm{~m}^{3} \mathrm{y}^{-1}$ produced by geothermal heating over this area, which was two orders of magnitude less than the contributions from runoff and ice discharge, and can therefore be ignored (Tables 2 and 3). For (b), the maximum rate of basal melt due to frictional heating caused by ice sliding over the bed is Eq. (1):

$m=(t b \times u b) /(\rho \times L f)$

where, $t b$ is the basal shear stress, $u b$ is sliding speed, $\rho$ is the ice density, and Lf is the latent heat of freezing/melting. Again, it was assumed that the bed was at the melting temperature over the drainage area with surface elevations below $1200 \mathrm{~m}$ a.s.l. We also assumed that $100 \%$ of the ice motion needed to maintain mass balance (i.e., the balance velocity) was accomplished through basal sliding in this region. Balance velocities were obtained from Bamber et al. (2000). Finally, we assumed that the basal drag was equal to the driving stress, which we calculated from the ice thickness and surface elevation maps from Bamber et al. (2000, 2001). From this we obtain a total melt volume rate of approximately $0.5 \times 10^{9} \mathrm{~m}^{3} \mathrm{y}^{-1}$, which is approximately $1 \%$ of the average total freshwater flux (Table 3).

\section{Results and discussion}

\subsection{Terrestrial surface runoff to Sermilik Fjord}

Annual (1999-2008) cumulative simulated runoff from all seven sub-catchments, and from the entire catchment, to Sermilik Fjord is shown in Fig. 4b. Total runoff to Sermilik Fjord for the modeled decade averaged $4.6 \pm 0.7 \times 10^{9} \mathrm{~m}^{3} \mathrm{y}^{-1}$, from a minimum of $2.9 \pm 0.4 \times 10^{9} \mathrm{~m}^{3} \mathrm{y}^{-1}$ in 1999 to a maximum of $5.9 \pm 0.9 \times 10^{9} \mathrm{~m}^{3} \mathrm{y}^{-1}$ in 2005 ; these values were expected to be among the highest since the simulation period included the warmest years since the beginning of instrumental records. For the simulation period, data showed an average insignificant increase in runoff of $1.0 \times 10^{9} \mathrm{~m}^{3}\left(r^{2}=0.14\right.$, $p<0.25$; where $p$ level of significance) (Fig. 4b), due to a combination of both increasing annual precipitation $\left(r^{2}=0.13\right)$ and increasing mean annual summer air temperature (June through August) $\left(r^{2}=0.32\right)$, influencing the melting snow and ice conditions. An increase in precipitation for the Sermilik Fjord catchment of $\sim 15 \%$ decade $^{-1}$, which was above the average increase of $\sim 1 \%$ decade $^{-1}$ for the Arctic in general, estimated by ACIA (2005).

For the simulation period, 2007 showed the largest satellite-derived GrIS cumulative melt extent followed by 2005 (Steffen et al., 2008), but also the largest melt index - defined as the melting area times the number of melting days for areas above $2000 \mathrm{~m}$ in elevation (Tedesco, 2007) followed by 2005 as the fourth highest for the simulation period. The largest amount of modeled runoff to the Sermilik Fjord occurred in 2005, and not in 2007 (Fig. 4b). This discrepancy between the GrIS melting conditions and the Sermilik Fjord runoff conditions was due to a record high annual precipitation for 2005 of $\sim 180 \mathrm{~mm}$ w.eq. $\mathrm{y}^{-1}$ combined with the second highest mean annual summer air temperatures of $2.2^{\circ} \mathrm{C}$ (Fig. 2a). The record high 2005 precipitation combined with the relatively high percentage of rain $(\sim 65 \%$ of the total annual precipitation) was the reason why less precipitation accumulated as snow during winter, and more streamed directly into the fjord as runoff. The connection between snow melting, melt water retention and refreezing within the snowpack, and runoff is described, e.g., in Hanna et al. (2008), Mernild et al. (2009) related to the variation in annual snow accumulation/precipitation.

Weather conditions for SE Greenland, including the Sermilik Fjord, are affected by low-pressure systems (e.g., Tsukernik et al., 2007), especially the associated wind and precipitation which varies due to year-to-year changes in the storm tracks. Most low pressure centers arrive from directions between south and west, steered by the "polar vortex", an upper level cyclone. During winter these are normally centered over the Canadian Cold Pole and during summers they are less pronounced and centered over the Arctic Ocean (Hansen et al., 2008). Therefore, it should be kept in mind, even though maximum melting conditions occurred for the GrIS as in 2007, local variability in precipitation can be the reason for annual runoff peaks, as illustrated for the Sermilik Fjord catchment for 2005.

On a sub-catchment scale, the interannual runoff variability generally followed the variability of the overall runoff to the fjord, showing lowest runoff values in 1999 and highest values in 2005 (Fig. 4b). In Fig. 4b the spatial distribution of runoff to the Sermilik Fjord is illustrated, displaying that sub-area 7 contributed, on average, the lowest annual runoff volume of $0.4 \pm 0.1 \times 10^{9} \mathrm{~m}^{3} \mathrm{y}^{-1}$, and subarea 4 the highest value of $1.4 \pm 0.2 \times 10^{9} \mathrm{~m}^{3} \mathrm{y}^{-1}$. Besides the general effect of precipitation and summer air temperatures on runoff from all sub-catchments, both the percentage of glacier cover and its hypsometry within each subcatchment strongly influenced simulated runoff within the region. Generally, sub-catchments showing high fractions of glacier cover and glaciers at low elevations show stronger positive runoff effects during years with high temperatures (Fig. 4c). 

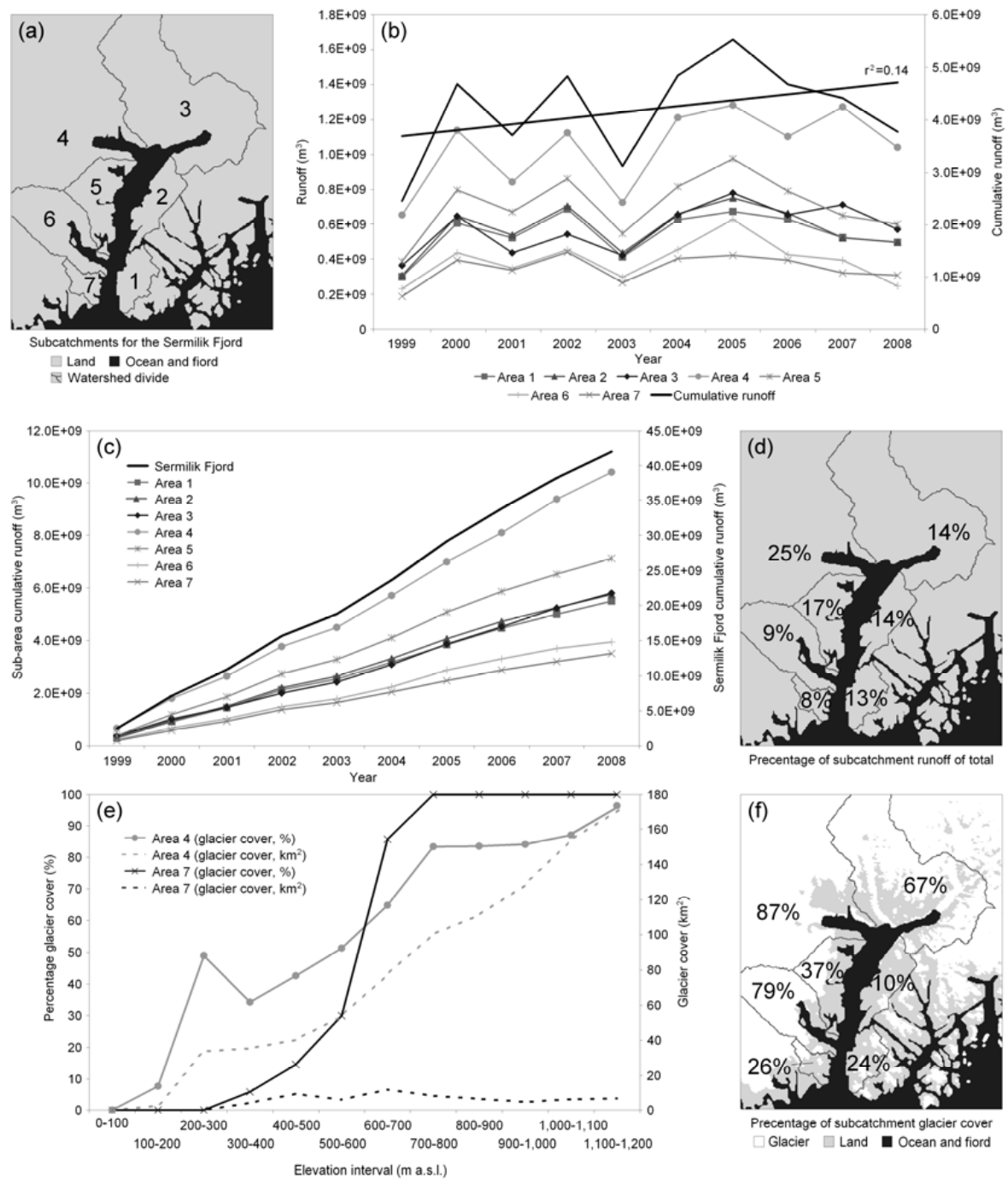

Fig. 4. (a) Area of interest including the seven sub-catchments for the Sermilik Fjord (simulated in River Tools); (b) time series (1999-2008) of annual sub-catchment simulated runoff and annual cumulative runoff, including trend line (linear) for cumulative runoff; (c) cumulative sub-catchment runoff and overall runoff; (d) percentage of sub-catchment runoff of total runoff; (e) glacier cover distribution in percentage and square kilometer within the elevations from where runoff occurred for the sub-catchment with the lowest cumulative runoff (subcatchment 7) and the highest (sub-catchment 4); and (f) the percentage of sub-catchment glacier cover within the area of interest.

The Sermilik Fjord accumulated catchment and subcatchment runoff (1999-2008) are illustrated in Fig. 4c, showing an overall cumulative freshwater runoff volume of $46.0 \pm 6.9 \times 10^{9} \mathrm{~m}^{3}$. The lowest cumulative runoff contribution occurred from sub-area 7 , with a total of $3.5 \pm 0.5 \times 10^{9} \mathrm{~m}^{3}$, which equalled about $8 \%$ of the overall freshwater runoff to the fjord. The highest contribution of $10.4 \pm 1.6 \times 10^{9} \mathrm{~m}^{3}$ came from sub-area 4 - the Helheim subcatchment - , which equalled about $25 \%$ of the overall runoff. The percentage of cumulative freshwater runoff from the other sub-areas (area 1-3 and 5-6) averaged from 9\% to 17\% of the overall runoff (Fig. 4d). Obviously sub-catchments with the greatest glacier coverage, combined with the highest percentage of glaciers at low elevations, were the sub-areas where the greatest freshwater runoff contribution to the fjord occurred, and vice versa. In Fig. 4e the differences between sub-catchments 4 and 7 in glacier cover $\left(\mathrm{km}^{2}\right)$ and in glacier cover (\%) within each 100-m elevation interval are shown. Area 4 was the sub-catchment having the greatest glacier area of $910 \mathrm{~km}^{2}$ from where runoff occurred: $\sim 30 \%$ of the area was located below 500-600 m a.s.l. Area 7 was, however, a sub-catchment having a glacier cover of only $65 \mathrm{~km}^{2}$ of which only $\sim 10 \%$ was found below $500-600 \mathrm{~m}$ a.s.l. Areas 1-3 and 5-6 represent a mixture of the main characteristics found in areas 4 and 7. Even though areas 3 and 6 both have a relatively high glacier cover of $67 \%$ and $79 \%$, respectively, the cumulative runoff only accounted for $14 \%$ and $9 \%$ of the overall runoff to the fjord (Fig. 4d). The reason for these 

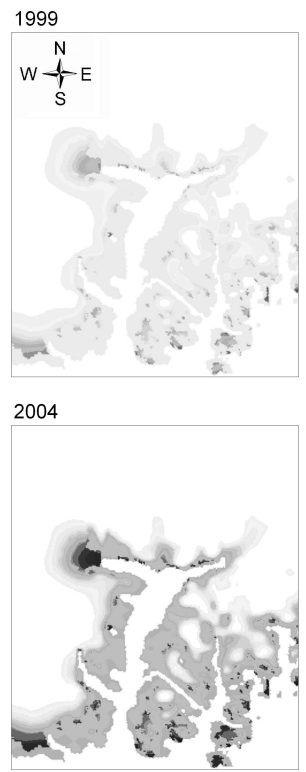

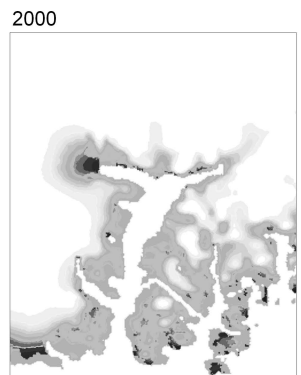

2005

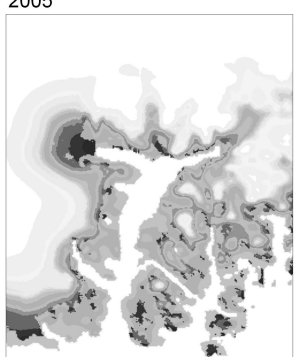

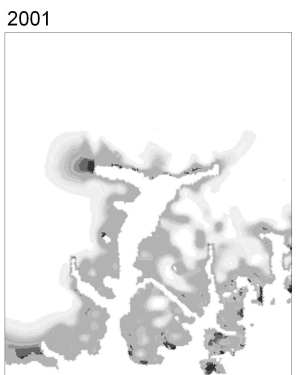

2006

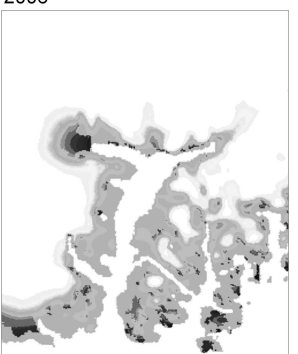

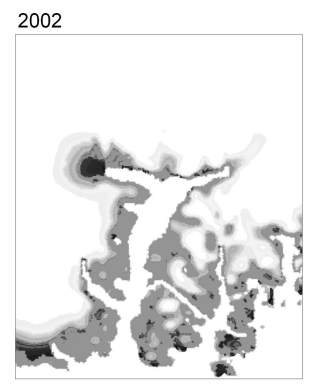

2007

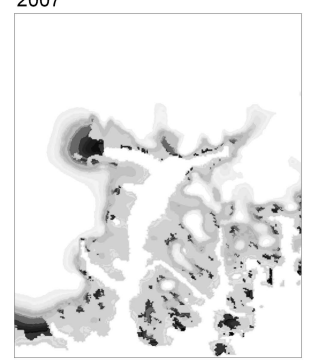

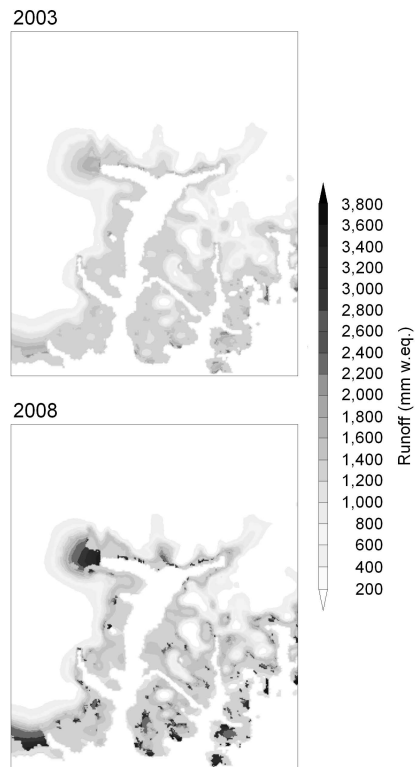

Fig. 5. Spatial simulated annual cumulative runoff within the area of interest to the Sermilik Fjord for 1999-2008.

relatively low percentages of runoff values from sub-area 3 and 6 were due to the high elevated glacier cover within each sub-catchment. For sub-area 5 the situation was however different: In area 5 the amount of runoff accounted for $17 \%$ of the overall runoff to Sermilik Fjord, even though the subcatchment area and the glacier cover area were relatively low. The reason for the relatively high runoff volume from subarea 5 was because of the low elevated glacier cover in the sub-area.

In Fig. 5 the spatial distributions of annual cumulative runoff to Sermilik Fjord are illustrated for 1999 through 2008. Those parts of the fjord catchment exhibiting glaciers covering low altitudes, e.g., both marginal glaciers and the Helheim glacier terminus showed the highest simulated runoff values. At the Helheim glacier terminus the areally-averaged annual maximum runoff ranged from $\sim 1.8 \mathrm{~m}$ w.eq. in 2003 to more than $\sim 3.8 \mathrm{~m}$ w.eq. in 2007. Simulated runoff values which seemed to be in line with previously published values, e.g., by Ettama et al. (2008), and consistent with previous GrIS runoff simulations by Mernild et al. (2009). The amount of simulated runoff decreased with increasing altitude, on average by $\sim 250 \mathrm{~mm}$ w.eq. $100 \mathrm{~m}^{-1}$ from the ice margin all the way to the boundary where runoff occurs (Fig. 5); for the Jakobshavn drainage area, W Greenland $\left(69^{\circ} \mathrm{N}\right)$, the value was similar with $\sim 220 \mathrm{~mm}$ w.eq. $100 \mathrm{~m}^{-1}$ (Mernild et al., 2010b). On the GrIS within the Sermilik Fjord catchment (for a latitude range of $65-66^{\circ} \mathrm{N}$ ) this annual runoff boundary line was located about $25-40 \mathrm{~km}$ from the GrIS terminus at an elevation of $1140 \mathrm{~m}$ a.s.l. to $1600 \mathrm{~m}$ a.s.l., averaging $1150 \pm 140 \mathrm{~m}$ a.s.l.

\subsection{Freshwater flux to Sermilik Fjord}

To account for the freshwater flux to the Sermilik Fjord, not only terrestrial surface runoff needs to be addressed, but also: (1) ice discharge influenced by GrIS dynamical processes (as described by Howat et al., 2005, 2008) and temperature of near-coastal ocean currents (Holland et al., 2008; Straneo et al., 2010); (2) seasonal changes in internal drainage system due to melting; (3) runoff from subglacial geothermal melting and frictional melting due to basal ice motion; (4) submarine melting at tidewater glacier margins; and (5) precipitation (e.g., rain and snow accumulation on sea ice) at the Sermilik Fjord surface area. Unfortunately, seasonal changes in internal drainage system was omitted, due to missing data (values probably insignificant related to the overall terrestrial freshwater flux budget to the Sermilik Fjord), while submarine melting at tidewater glacier margins was integrated in the ice discharge values. Contributions of ice discharge from minor GrIS outlet glaciers, e.g., glaciers located in Johan Petersens Fjord were ignored due to lack of available data (only a minor production of icebergs has been observed; personal communication, N. T. Knudsen, 2010), while ice discharge from the three major outlet glaciers: the Helheim Glacier, Fenris Glacier, and Midgård Glacier at the innermost part of the fjord were included (Figs. 6 and 7). Based on satellite-derived observations, the Helheim average ice discharge for the period 19992008 , was estimated to be $25.9 \pm 2.6 \times 10^{9} \mathrm{~m}^{3}$ w.eq. $\mathrm{y}^{-1}$ (Tables 2 and 3), and for the Fenris and Midgård Glaciers ice discharge were $2.5 \pm 0.5$ and $5.5 \pm 1.0 \times 10^{9} \mathrm{~m}^{3}$ w.eq. $\mathrm{y}^{-1}$, respectively (Table 3 and Fig. 6). In Fig. 6 an example of variations in surface ice velocity, ice thickness, and 

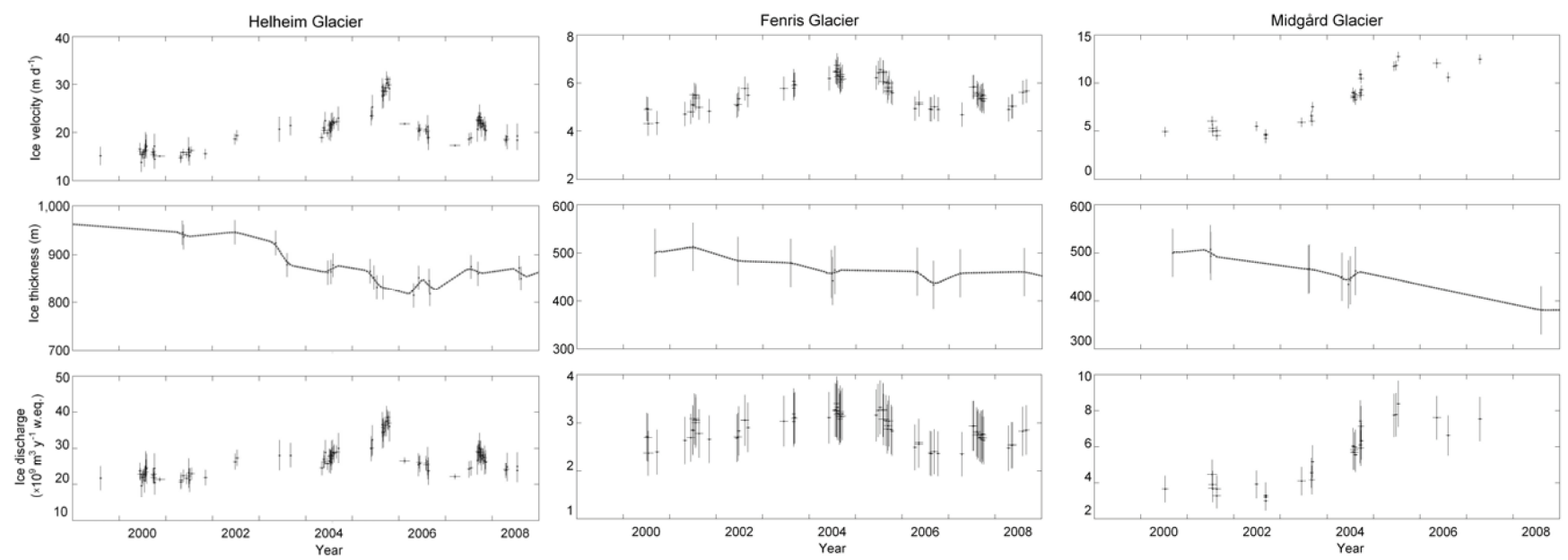

Fig. 6. Satellite-derived time series for the period 1998-2008 of ice velocity, ice thickness, and ice discharge at a stationary flux gate within $3 \mathrm{~km}$ of the most-retreated front position of the three major outlet glaciers: Helheim Glacier, Fenris Glacier, and Midgård Glacier draining into the Sermilik Fjord. Ice thickness observations (denoted by vertical error bars) were linearly interpolated, denoted by the curve, and multiplied by constant glacier width and observations of ice velocity and the ratio of water and ice densities (0.91) to obtain discharge of water. Ice discharge data for Helheim Glacier reported here are updated from Howat et al. (2005, 2007). Fenris and Midgård Glaciers are located in sub-area 3 and Helheim in sub-area 4.

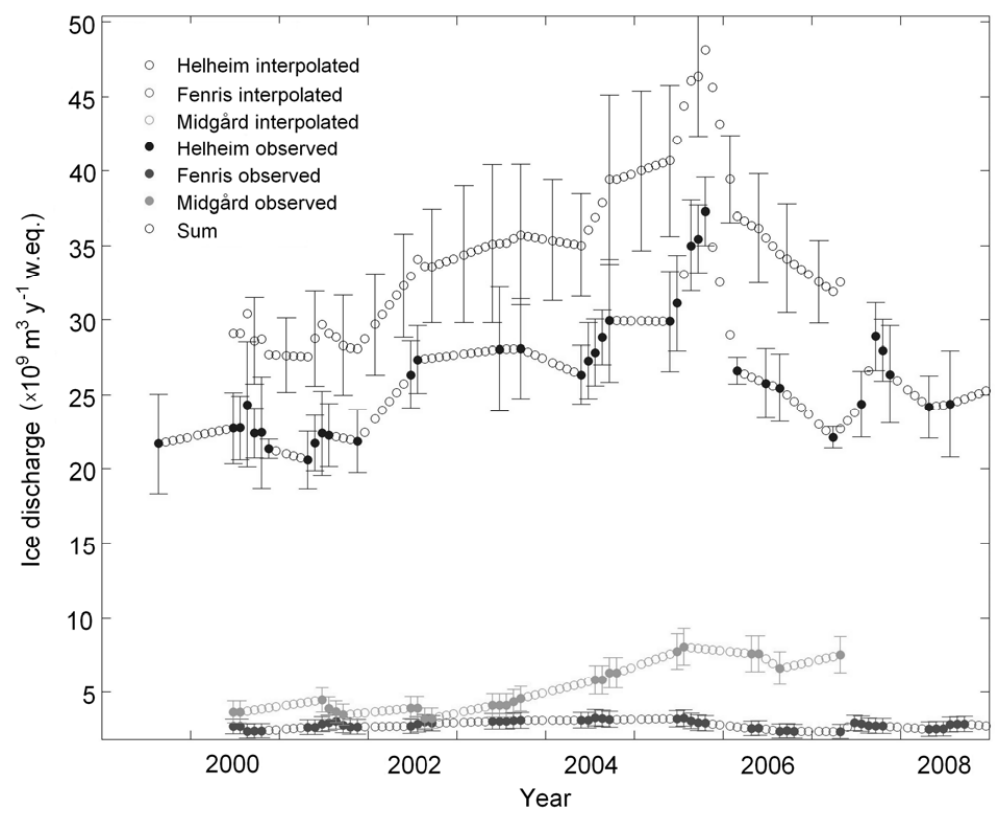

Fig. 7. Average monthly ice discharge observations (closed circle) and linearly-interpolated values (open circle) for Helheim Glacier, Fenris Glacier, and Midgård Glacier, and sum of the three glaciers for the period 1999 through 2008.

ice discharge for the Helheim Glacier, Fenris Glacier, and Midgård Glacier are illustrated, showing substantial variations in velocity, ice thickness, and discharge, with a general increase in velocity and discharge after 2002 and peaking in 2005 and 2006. Due to both decreased ice velocity and thickness, ice discharge at Helheim Glacier decreased to earlier levels by 2007 (Howat et al., 2007). However, for the simulation period, ice discharge from the three ma- jor outlet glaciers showed an average significant increase of $13.2 \times 10^{9} \mathrm{~m}^{3}$ w.eq. $\left(r^{2}=0.49 ; p<0.01\right)$ (Fig. 7$)$. Mean annual ice discharge values were combined with annual SnowModel simulated precipitation at the Sermilik Fjord surface area, terrestrial surface runoff, and subglacial geothermal and frictional melting, to deduce the freshwater flux: (1) from the Helheim Glacier catchment (Table 2), but also; (2) to the entire Sermilik Fjord (Table 3). Calculations 
Table 2. Freshwater flux from the Helheim Glacier catchment based on SnowModel simulated freshwater runoff and satellite-derived ice discharge.

\begin{tabular}{|c|c|c|c|c|c|c|c|c|c|c|c|}
\hline & 1999 & 2000 & 2001 & 2002 & 2003 & 2004 & 2005 & 2006 & 2007 & 2008 & Mean \\
\hline $\begin{array}{l}\text { SnowModel simulated } \\
\text { runoff from the Helheim } \\
\text { Glacier catchment in- } \\
\text { cluding error (sub-area } \\
\text { 4), } 10^{9} \mathrm{~m}^{3} \mathrm{y}^{-1}\end{array}$ & $0.7 \pm 0.1$ & $1.1 \pm 0.2$ & $0.8 \pm 0.1$ & $1.1 \pm 0.2$ & $0.7 \pm 0.1$ & $1.2 \pm 0.2$ & $1.3 \pm 0.2$ & $1.1 \pm 0.2$ & $1.3 \pm 0.2$ & $1.0 \pm 0.2$ & $1.0 \pm 0.2(4 \%)$ \\
\hline $\begin{array}{l}\text { Satellite-derived ice dis- } \\
\text { charge from the Helheim } \\
\text { Glacier including error, } \\
10^{9} \mathrm{~m}^{3} \mathrm{y}^{-1}\end{array}$ & $21.7 \pm 3.3$ & $22.7 \pm 2.5$ & $21.8 \pm 2.2$ & $26.8 \pm 2.3$ & $28.1 \pm 3.8$ & $28.0 \pm 2.5$ & $33.8 \pm 2.8$ & $25.9 \pm 1.8$ & $25.9 \pm 2.1$ & $24.3 \pm 2.8$ & $25.9 \pm 2.6(96 \%)$ \\
\hline $\begin{array}{l}\text { Freshwater flux from the } \\
\text { Helheim Glacier catch- } \\
\text { ment, } 10^{9} \mathrm{~m}^{3} \mathrm{y}^{-1}\end{array}$ & $22.4 \pm 3.4$ & $23.8 \pm 2.7$ & $22.6 \pm 2.3$ & $27.9 \pm 2.5$ & $28.8 \pm 3.9$ & $29.2 \pm 2.7$ & $35.1 \pm 3.0$ & $27.0 \pm 2.0$ & $27.2 \pm 2.3$ & $25.3 \pm 3.0$ & $26.9 \pm 2.8$ \\
\hline
\end{tabular}

Table 3. Freshwater flux to the Sermilik Fjord based on SnowModel simulated freshwater runoff, precipitation at the Sermilik Fjord surface area, subglacial geothermal melting and subglacial frictional melting due to basal ice motion, and satellite-derived ice discharge from the Helheim Glacier, Fenris Glacier, and Midgård Glacier (the three major outlet glaciers in Sermilik Fjord catchment). Mean freshwater flux to the Sermilik Fjord is calculated based on mean values from each input component.

\begin{tabular}{|c|c|c|c|c|c|c|c|c|c|c|c|c|}
\hline & 1999 & 2000 & 2001 & 2002 & 2003 & 2004 & 2005 & 2006 & 2007 & 2008 & \multicolumn{2}{|l|}{ Mean } \\
\hline $\begin{array}{l}\text { SnowModel simulated terrestrial } \\
\text { runoff to the Sermilik Fjord in- } \\
\text { cluding error, } 10^{9} \mathrm{~m}^{3} \mathrm{y}^{-1}\end{array}$ & $2.9 \pm 0.4$ & $5.1 \pm 0.8$ & $4.1 \pm 0.6$ & $5.2 \pm 0.8$ & $3.5 \pm 0.5$ & $5.2 \pm 0.8$ & $5.9 \pm 0.9$ & $5.1 \pm 0.8$ & $4.8 \pm 0.7$ & $4.2 \pm 0.6$ & \multicolumn{2}{|l|}{$4.6 \pm 0.7(11 \%)$} \\
\hline $\begin{array}{l}\text { SnowModel simulated precipita- } \\
\text { tion (e.g., rain and snow accumu- } \\
\text { lation on sea ice) at the Sermilik } \\
\text { Fjord surface area }\left(1103 \mathrm{~km}^{2}\right) \text { in- } \\
\text { cluding error, } 10^{9} \mathrm{~m}^{3} \mathrm{y}^{-1}\end{array}$ & $0.9 \pm 0.1$ & $1.2 \pm 0.1$ & $1.7 \pm 0.1$ & $1.7 \pm 0.1$ & $1.4 \pm 0.1$ & $1.4 \pm 0.1$ & $1.8 \pm 0.1$ & $1.4 \pm 0.1$ & $1.5 \pm 0.1$ & $1.3 \pm 0.1$ & \multicolumn{2}{|l|}{$1.4 \pm 0.1(3 \%)$} \\
\hline $\begin{array}{l}\text { Subglacial geothermal melting, } \\
10^{9} \mathrm{~m}^{3} \mathrm{y}^{-1}\end{array}$ & 0.01 & 0.01 & 0.01 & 0.01 & 0.01 & 0.01 & 0.01 & 0.01 & 0.01 & 0.01 & \multicolumn{2}{|l|}{$0.01(>0.03 \%)$} \\
\hline $\begin{array}{l}\text { Subglacial frictional melting due } \\
\text { to basal ice motion, } 10^{9} \mathrm{~m}^{3} \mathrm{y}^{-1}\end{array}$ & 0.5 & 0.5 & 0.5 & 0.5 & 0.5 & 0.5 & 0.5 & 0.5 & 0.5 & 0.5 & \multicolumn{2}{|l|}{$0.5(1 \%)$} \\
\hline $\begin{array}{l}\text { Satellite-derived ice discharge } \\
\text { from the Helheim Glacier includ- } \\
\text { ing error, } 10^{9} \mathrm{~m}^{3} \mathrm{y}^{-1}\end{array}$ & $21.7 \pm 3.3$ & $22.7 \pm 2.5$ & $21.8 \pm 2.2$ & $26.8 \pm 2.3$ & $28.1 \pm 3.8$ & $28.0 \pm 2.5$ & $33.8 \pm 2.8$ & $25.9 \pm 1.8$ & $25.9 \pm 2.1$ & $24.3 \pm 2.8$ & $25.9 \pm 2.6(65 \%)$ & \multirow{3}{*}{$\begin{array}{l}\stackrel{2}{\infty} \\
\dot{\infty} \\
\stackrel{\infty}{+} \\
\dot{+} \\
\dot{H} \\
\dot{m}\end{array}$} \\
\hline $\begin{array}{l}\text { Satellite-derived ice discharge } \\
\text { from the Fenris Glacier including } \\
\text { error, } 10^{9} \mathrm{~m}^{3} \mathrm{y}^{-1}\end{array}$ & - & $2.3 \pm 0.5$ & $2.5 \pm 0.5$ & $2.6 \pm 0.5$ & $2.8 \pm 0.5$ & $2.9 \pm 0.5$ & $2.8 \pm 0.5$ & $2.2 \pm 0.5$ & $2.5 \pm 0.5$ & $2.4 \pm 0.5$ & $2.5 \pm 0.5(6 \%)$ & \\
\hline $\begin{array}{l}\text { Satellite estimated ice discharge } \\
\text { from the Midgård Glacier includ- } \\
\text { ing error, } 10^{9} \mathrm{~m}^{3} \mathrm{y}^{-1}\end{array}$ & - & $3.7 \pm 0.7$ & $3.9 \pm 0.8$ & $3.6 \pm 0.7$ & $4.2 \pm 0.8$ & $6.1 \pm 1.0$ & $7.9 \pm 1.2$ & $7.3 \pm 1.2$ & $7.5 \pm 1.2$ & - & $5.5 \pm 1.0(14 \%)$ & \\
\hline $\begin{array}{l}\text { Freshwater flux to the Sermilik } \\
\text { Fjord, } 10^{9} \mathrm{~m}^{3} \mathrm{y}^{-1}\end{array}$ & - & $35.5 \pm 4.6$ & $34.5 \pm 4.2$ & $40.4 \pm 4.4$ & $40.5 \pm 5.7$ & $44.1 \pm 4.9$ & $52.7 \pm 5.5$ & $42.4 \pm 4.4$ & $42.7 \pm 4.6$ & - & $40.4 \pm 4.9$ & \\
\hline
\end{tabular}

showed a freshwater flux averaging $26.9 \pm 2.8 \times 10^{9} \mathrm{~m}^{3} \mathrm{y}^{-1}$ from the Helheim Glacier sub-catchment, and a flux of $40.4 \pm 4.9 \times 10^{9} \mathrm{~m}^{3} \mathrm{y}^{-1}$ to the Sermilik Fjord for 1999-2008. The suggested freshwater flux entering the Sermilik Fjord of $40.4 \pm 4.9 \times 10^{9} \mathrm{~m}^{3} \mathrm{y}^{-1}$, equaled $5 \%$ of the freshwater flux of $786 \times 10^{9} \mathrm{~m}^{3} \mathrm{y}^{-1}$ (1995-2007) from the entire GrIS to the ocean (Mernild et al., 2009). For the Helheim Glacier catchment, around $25.9 \pm 2.6 \times 10^{9} \mathrm{~m}^{3} \mathrm{y}^{-1}(96 \%)$ originated from satellite-derived ice discharge, and $1.0 \pm 0.2 \times 10^{9} \mathrm{~m}^{3} \mathrm{y}^{-1}$ (4\%) from SnowModel simulated runoff. For Sermilik Fjord $4.6 \pm 0.7 \times 10^{9} \mathrm{~m}^{3} \mathrm{y}^{-1}(11 \%)$ out of a freshwater flux of $40.4 \pm 4.9 \times 10^{9} \mathrm{~m}^{3} \mathrm{y}^{-1}$, originated from the SnowModel simulated runoff, $1.4 \pm 0.1 \times 10^{9} \mathrm{~m}^{3} \mathrm{y}^{-1}$ (3\%) from the SnowModel simulated precipitation at the Sermilik Fjord surface area, $33.9 \pm 4.1 \times 10^{9} \mathrm{~m}^{3} \mathrm{y}^{-1}(85 \%)$ from ice discharge, and $0.5 \times 10^{9} \mathrm{~m}^{3} \mathrm{y}^{-1}(1 \%)$ from subglacial frictional melting due to basal ice motion (Table 3 ). In general, ice discharge represented $65 \%, 14 \%$, and $6 \%$ of the total freshwater flux from Helheim, Midgård, and Fenris glaciers, respectively (Table 3). For GrIS in total, around half of the mass loss originated by surface melting and subsequent freshwater runoff into the ocean, and the other half from iceberg calving and geothermal melting (e.g., Rignot and Kanagaratnam 2006, Lemke et al. 2007, Mernild et al. 2008c). 
The Helheim Glacier represents one of the major outlet glaciers from the GrIS, which dominated $65 \%$ of the freshwater flux into Sermilik Fjord. Runoff only forms a minor part $(11 \%)$ of the overall freshwater flux to the fjord. Similar conditions were found for the Jakobshavn drainage area (2000-2007), where 7\% of the average annual freshwater flux originated from surface runoff (Mernild et al., 2010b). For two of the major GrIS outlet glacier sub-catchments (Helheim and Jakobshavn) it can be concluded that runoff was a minor contributor to the freshwater flux, which was highly dominated by ice discharge.

\section{Summary and conclusion}

The amount of freshwater runoff reaching the ocean from marginal glaciers, the GrIS, and ice free landscapes depends on the precipitation and storage changes in reservoirs of ice, snow, and water on land. In many places around Greenland, glaciers calve directly into the sea and the overall flux of freshwater from specific catchments, e.g., the Sermilik Fjord catchment, will be influenced by or even dominated by a discharge of calving ice. At the Sermilik Fjord catchment, $85 \%$ of the average annual freshwater flux of $40.4 \pm 4.9 \times 10^{9} \mathrm{~m}^{3} \mathrm{y}^{-1}$ (1999-2008) originated from ice discharge $(65 \%$ alone from the Helheim Glacier), $11 \%$ from terrestrial surface runoff, $3 \%$ from net precipitation at the fjord area, and $1 \%$ from subglacial frictional melting. Ice discharge is the primary mechanism for delivering freshwater to Sermilik Fjord. In period of a warmer climate, as for example during the recent decade an increase in runoff $\left(r^{2}=0.14\right)$ and ice discharge $\left(r^{2}=0.49\right)$ occurred. The Sermilik Fjord increasing runoff was caused by both increasing mean annual summer air temperature and precipitation: even though maximum melting conditions occurred in 2007 , local variability in precipitation can be the reason for annual runoff peaks, as illustrated for the Sermilik Fjord for 2005.

Acknowledgements. Special thanks to the Danish Meteorological Institute, the Cooperative Institute for Research in Environmental Sciences (CIRES), University of Colorado at Boulder, the Department of Geography and Geology, University of Copenhagen, and the Geological Survey of Denmark and Greenland (GEUS) for use of observed meteorological data. Further, thanks to the Department of Geography and Geology, University of Copenhagen, for use of observed runoff data. Thanks are also given to Byrd Polar Research Center, Ohio State University, for use of satellite-derived ice discharge. This work was supported by grants from the Climate Change Prediction Program within the US Department of Energy's Office of Science. Los Alamos National Laboratory is operated under the auspices of the National Nuclear Security Administration of the US Department of Energy under Contract No. DE-AC52-06NA25396.

Edited by: S. Dery

\section{References}

ACIA: Arctic Climate Impact Assessment, Cambridge University Press, 1042 pp., 2005.

Ahn, Y. and Howat, I. M.: Efficient, automated glacier surface velocity measurements from repeat images using multiimage/multi-chip (MIMC) feature tracking, IEEE T. Geosci. Remote, revised, 2010.

Allerup, P., Madsen, H., and Vejen, F.: Estimating true precipitation in Arctic areas, Proc. Nordic Hydrological Conf., Helsinki, Finland, Nordic Hydrological Programme Rep. 44, 1-9, 1998.

Allerup, P., Madsen, H., and Vejen, F.: Correction of precipitation based on off-site weather information. Atmos. Res., 53, 231-250, 2000.

Allison, I., Bindoff, N. L., Bindschadler, R. A., Cox, P. M., de Noblet, N., England, M. H., Francis, J. E., Gruber, N., Haywood, A. M., Karoly, D. J., Kaser, G., Le Quéré, C., Lenton, T. M., Mann, M. E., McNeil, B. I., Pitman, A. J., Rahmstorf, S., Rignot, E., Schellnhuber, H. J., Schneider, S. H., Sherwood, S. C., Somerville, R. C. J., Steffen, K., Steig, E. J., Visbeck, M., and Weaver, A. J.: The Copenhagen Diagnosis: Updating the World on the Latest Climate Science, The University of New South Wales Climate Change Research Centre (CCRC), Sydney, Australia, 60 pp., 2009.

Bamber, J., Ekholm, S., and Krabill, W.: A new, high-resolution digital elevation model of Greenland fully validated with airborne laser altimeter data, J. Geophys. Res., 106, 6733-6746, 2001.

Bamber J., Hardy, R. J., and Joughin, I.: An analysis of balance velocities over the Greenland Ice Sheet and comparison with synthetic aperture radar interferometry, J. Glaciol., 46(152), 10, 6774, 2000.

Born, E. W. and Böcher, J.: The Ecology of Greenland, Nuuk, Ministry of Environment and Natural Resources, 429 pp. 2001.

Box, J. E., Bromwich, D. H., and Veenhuis, B. A., et al.: Greenland Ice Sheet surface mass balance variability (1998-2004) from calibrated polar MM5 output, J. Climate, 19, 2783-2800, 2006.

Busskamp, R. and Hasholt, B.: Coarse bed load transport in a glacial valley, Sermilik, South East Greenland, Z. Geomorphol., 40, 349-358, 1996.

Cuffey, K. M. and Paterson, W. S. B.: The Physics of Glaciers, $4^{\text {th }}$ edn., Butterworth-Heinemann, Oxford, 704 pp., 2010.

Ettema, J., van den Broeke, M., van Meijgaard, E., van de Berg, M. J., Bamber, J. L., Box, J. E., and Bales, R. C.: Higher surface mass balance of the Greenland Ice Sheet revealed by high resolution climate modeling, Geophys. Res. Lett., 36, L12501, doi:10.1029/2009GL038110, 2009.

Gogineni, S., Tammana, D., Braaten, D., et al.: Coherent radar ice thickness measurements over Greenland Ice Sheet, J. Geophys. Res., 106, 33761-33772, 2001.

Hanna, E., Huybrechts, P., Steffen, K., et al.: Increased runoff from melt from the Greenland Ice Sheet: a response to global warming, J. Climate, 21, 331-341, 2008.

Hansen, B. U., Sigsgaard, C., Rasmussen, L., Cappelen, J., Hinkler, J., Mernild, S. H., Petersen, D., Tamstorf, M., Rasch, M., and Hasholt, B.: Present day climate at Zackenberg, Adv. Ecol. Res., 40, 115-153, 2008.

Hasholt, B.: Morphological and hydrological possibilities for the development of water power at Angmassalik - a case study of applied physical geography, Geogr. Tidsskr., 80, 57-62, 1980. 
Hasholt, B., Bobrovitskaya, N., Bogen, J., McNamara, J., Mernild, S. H., Milbourn, D., and Walling, D. E.: Sediment transport to the Arctic Ocean and adjoining cold oceans, Nord. Hydrol., 37(4-5), 413-432, 2006.

Hasholt, B., Liston, G. E., and Knudsen, N. T.: Snow-distribution modelling in the Ammassalik Region, South East Greenland, Nord. Hydrol., 34(1/2), 1-16, 2003.

Hasholt, B. and Mernild, S. H.: Estimation of water balance in and around the Mittivakkat Glacier basin, Ammassalik Island, Southeast Greenland, in: Northern Research Basins Water Balance, edited by: Kane, D. L. and Yang, D., Wallingford, UK, IAHS, 129-142, publications no. 290, ISBN 1-901502-82-1, 2004.

Hasholt, B. and Mernild, S. H.: Hydrology, sediment transport, and water resources of Ammassalik Island, SE Greenland, Geogr. Tidsskr., 108(1), 73-95, 2008.

Hasholt, B., Mernild, S. H., Sigsgaard, C., Elberling, B., Petersen, D., Jakobsen, B. H., Hansen, B. U., Hinkler, J., and Søgaard, H.: Hydrology and transport of sediment and solutes at Zackenberg, in: High-Arctic Ecosystem Dynamics in a Changing Climate: Ten Years of Monitoring and Research at Zackenberg Research Station, Northeast Greenland, edited by: Meltofte, H., Christensen, T. R., Elberling, B., Forchhammer, M. C., and Rasch, M.: Hydrology and transport of sediment and solutes at Zackenberg, Adv. Ecol. Res., 40, 111-149, 2008.

Hasholt, B. and Walling, D. E.: Use of caesium-137 to investigate sediment sources and sediment delivery in a small glacierzed mountain drainage basin in eastern Greenland, in: Erosion, Debris Flows and Environment in Mountain Regions, IAHS, Publ. 209, 87-99, 1992.

Holland, D. M., Thomas, R. H., de Young, B., Ribergaard, M. H., and Lyberth, B.: Acceleration of Jakobshavn Isbræ triggered by warm subsurface ocean waters, Nat. Geosci., 1(10), 659-664, 2008.

Howat, I. M., Joughin, I., Tulaczyk, S., and Gogineni, S.: Rapid retreat and acceleration of Helheim Glacier, East Greenland, Geophys. Res. Lett., 32, L22502, doi:10.1029/2005GL024737, 2005.

Howat, I. M., Joughin, I., and Scambos, T.: Rapid changes in ice discharge from Greenland outlet glaciers, Science, 315, 1559, doi:10.1126/science.1138478, (advanced publication in Science Express on 8 February 2007), 2007.

IPCC: Summary for policymakers, in: Climate Change 2007, The Physical Science Basis, Contribution of Working Group I to the Fourth Assessment Report of the Intergovernmental Panel on Climate Change, edited by: Solomon, S., Qin, D., Manning, M., Chen, Z., Marquis, M., Averyt, K. B., Tignor, M., and Miller, H. L., Cambridge University Press, Cambridge, UK and New York, USA, 2007.

Jakobsen, B. H., Fredskild, B., and Pedersen, J. B. T.: Holocene changes in climate and vegetation in the Ammassalik area, East Greenland, recorded in lake sediment and soil profiles, Geogr. Tidsskr., 108(1), 21-50, 2008.

Jensen, L. M. and Rasch, M.: Zackenberg Ecological Research Operations, $14^{\text {th }}$ Annual Report 2008, National Environmental Research Institute, Aarhus University, Denmark, 116 pp., 2009.

Jujisada, H., Bailey, G. B., Kelly, G. G., Hara, S., and Abrams, M. J.: ASTER DEM performance, IEEE T. Geosci. Remote, 43(12), 2707-2714, 2005.

Khan, S. A., Wahr, J., Bevis, M., Velicogna, I., and Kendrick, E.: Spread of ice mass into Northwest Greenland observed, Geo- phys. Res. Lett., 37, L06501, doi:10.1029/2010GL042460, 2010.

Kozo, T. L.: An observational study of sea breezes along the Alaskan Beaufort Sea Coast: Part I, J. Appl. Meteorol., 21, 891905, 1982.

Knudsen, N. T. and Hasholt, B.: Mass balance observations at the Mittivakkat Gletscher, Southeast Greenland 1995-2002, Nord. Hydrol., 35(4-5), 381-390, 2004.

Knudsen, N. T. and Hasholt, B.: Mass balance observations at Mittivakkat Glacier, Ammasalik Island, Southeast Greenland 19952006, Geogr. Tidsskr., 108(1), 111-120, 2008.

Lemke, P., Ren, J., Alley, R. B., Allison, I., Carrasco, J., Flato, G., Fujii, Y., Kaser, G., Mote, P., Thomas, R. H., and Zhang, T.: Observations: Changes in Snow, Ice and Frozen Ground, in: Climate Change 2007: The Physical Science Basis. Contribution of Working Group I to the Fourth Assessment Report of the Intergovernmental Panel on Climate Change, edited by: Solomon, S., Qin, D., Manning, M., Chen, Z., Marquis, M., Averyt, K. B., Tignor, M., and Miller, H. L., Cambridge University Press, Cambridge, United Kingdom and New York, NY, USA, 2007.

Liston, G. E. and Elder, K.: A distributed snow-evolution modeling system (SnowModel), J. Hydrometeorol., 7, 1259-1276, 2006 a.

Liston, G. E. and Elder, K.: A meteorological distribution system for high-resolution terrestrial modeling (MicroMet), J. Hydrometeorol., 7, 217-234, 2006b.

Liston, G. E. and Hiemstra, C. A.: A simple data assimilation system for complex snow distributions (SnowAssim), J. Hydrometeorol., 9, 989-1004, 2008.

Liston, G. E. and Sturm, M.: A snow-transport model for complex terrain, J. Glaciol., 44, 498-516, 1998.

Mernild, S. H.: The internal drainage system of the lower Mittivakkat Glacier, Ammassalik Island, SE Greenland, Geogr. Tidsskr., 106(1), 13-24, 2006.

Mernild, S. H., Hansen, B. U., Jakobsen, B. H., and Hasholt, B.: Climatic conditions at the Mittivakkat Glacier catchment (19942006), Ammassalik Island, SE Greenland, and in a 109 years term perspective (1898-2006), Geogr. Tidsskr., 108(1), 51-72, 2008a.

Mernild, S. H. and Hasholt, B.: Climatic control on river discharge simulations, Mittivakkat Glacier catchment, Ammassalik Island, SE Greenland, Nord. Hydrol., 37(4-5), 327-346, 2006.

Mernild, S. H. and Hasholt, B.: Observed runoff, jökulhlaups, and suspended sediment load from the Greenland Ice Sheet at Kangerlussuaq, West Greenland, for 2007 and 2008. J. Glaciol., 55(193). 855-858, 2009.

Mernild, S. H., Hasholt, B., and Liston, G. E.: Water flow through Mittivakkat Glacier, Ammassalik Island, SE Greenland, Geogr. Tidsskr., 106(1), 25-43, 2006b.

Mernild, S. H. and Liston, G. E.: The influence of air temperature inversion on snow melt and glacier surface mass-balance simulations, SW Ammassalik Island, SE Greenland, J. Appl. Meteorol. Clim., 49(1), 47-67, 2010.

Mernild, S. H., Liston, G. E., Hasholt, B., and Knudsen, N. T.: Snow distribution and melt modeling for Mittivakkat Glacier, Ammassalik Island, SE Greenland, J. Hydrometeorol., 7, 808824, 2006a.

Mernild, S. H., Liston, G. E., Hiemstra, C. A. Christensen, J. H., Stendel, M. and Hasholt, B. Surface mass-balance and runoff modeling using HIRHAM4 RCM at Kangerlussuaq (Søndre Strømfjord), West Greenland, 1950-2080, in press, J. Climate, 
2011.

Mernild, S. H., Liston, G. E., Hiemstra, C. A., and Steffen, K.: Surface Melt Area and Water Balance Modeling on the Greenland Ice Sheet 1995-2005, J. Hydrometeorol., 9(6), 1191-1211, 2008c.

Mernild, S. H., Liston, G. E., Hiemstra, C. A., Steffen, K., Hanna, E., and Christensen, J. H.: Greenland Ice Sheet surface mass-balance modeling and freshwater flux for 2007, and in a 1995-2007 perspective, Hydrol. Process., 23(17), 2470-2484, doi:10.1002/hyp.7354, 2009.

Mernild, S. H., Liston, G. E., Kane, D. L., Hasholt, B., and Knudsen, N. T.: Spatial snow distribution, runoff, and mass balance modelling for entire Mittivakkat Glacier (1998-2006), Ammassalik Island, SE Greenland, Geogr. Tidsskr., 108(1), 121-136, 2008 b.

Mernild, S. H., Liston, G. E., Hiemstra, C. A., and Christensen, J. H.: Greenland Ice Sheet surface mass-balance modeling in a 131-year perspective 1950-2080, J. Hydrometeorol., 11(1), 325, 2010a.

Mernild, S. H., Liston, G. E., Steffen, K., and Chylek, P.: Meltwater flux and runoff modeling in the ablation area of the Jakobshavn Isbræ, West Greenland, J. Glaciol., 56(195), 20-32, 2010b.

Mote, T. L.: Greenland surface melt trends 1973-2007: evidence of a large increase in 2007, Geophys. Res. Lett., 34, L22507, doi:10.1029/2007GL031976, 2007.

Rignot, E., and Kanagaratnam P.: Changes in the Velocity Structure of the Greenland Ice Sheet, Science, 315, 1559-1561, 2006.

Rysgaard, S. and Glud, R. N.: Carbon cycling in Arctic marine ecosystems: case study young sound, Meddr. om Grønland, Bioscience, 58, 24-43, 2007.
Scambos, T. and Haran, T.: An image-enhanced DEM of the Greenland ice sheet, Ann. Glaciol., 34, 291-298, 2002.

Screen, J. A. and Simmonds, I.: The central role of diminishing sea ice in recent Arctic temperature amplification. Nature, 464: 1334-1337, 2010.

Steffen, K. and Box, J. E.: Surface climatology of the Greenland ice sheet: Greenland Climate Network 1995-1999, J. Geophys. Res., 106, 33951-33964, doi:10.1029/2001JD900161, 2001.

Steffen, K., Clark, P. U., Cogley, J. G., Holland, D., Marshall, S., Rignot, E., and Thomas, R.: Rapid changes in glacier and ice sheet and their impacts on sea level, in: Abrupt Climate Change, a Report by the US Climate Change Science Program and the Subcommittee on Global Change Research, US Geological Survey, reston, VA, 60-142, 2008.

Straneo, F., Hamilton, G. S., Sutherland, D. A., Stearne, L. A., Davidson, F., Hammill, M. O., Stenson, G. B., and RosingAsvid, A.: Rapid circulation of warm subtropical waters in a major glacial fjord in East Greenland, Nat. Geosci., 3(3), 182186, 2010.

Tedesco, M.: A new record in 2007 for melting in Greenland, EOS T. Am. Geophys. Un., 88(39), 383 pp., 2007.

Tsukernik, M., Kindig, D. N., and Serreze, M. C.: Characteristics of winter cyclone activity in the northern North Atlantic: Insights from observations and regional modeling, J. Geophys. Res., 112, C03101, doi:10.1029/2006JD007184, 2007.

Velicogna, I. and Wahr, J.: Acceleration of Greenland ice mass loss in spring 2004, Nature, 443, 329-331, 2006.

Weick, E. J. and Rouse, W. R.: Advection in the coastal Hudson Bay Lowlands, Canada, II, Impact of atmospheric divergence on the surface energy balance, Arctic Alpine Res., 23, 338-348, 1991. 